\title{
Sacadura Cabral and the Dawn of Portuguese Aviation
}

\author{
Fernando M. S. P. Neves, Jorge M. M. Barata, André R. R. Silva \\ Aerospace Sciences Department, Universidade da Beira Interior, Covilhã, Portugal \\ Email: fernandomneves@gmail.com
}

Received 14 December 2015; accepted 18 January 2016; published 21 January 2016

Copyright (C) 2016 by authors and Scientific Research Publishing Inc.

This work is licensed under the Creative Commons Attribution International License (CC BY).

http://creativecommons.org/licenses/by/4.0/

(c) (i) Open Access

\begin{abstract}
Sacadura Cabral was one of the two Portuguese navigators that crossed by air the South Atlantic in the beginning of the $20^{\text {th }}$ century. From 1901 to 1915 Sacadura was at Mozambique and Angola where he developed geodetic and geographical missions of the greatest importance for Portuguese interest at Africa. With the Great World War requirements as a Navy Officer with 34 years old he decided to serve Portugal at the Aviation. In 1915 he went to France and obtained its pilot license. In 1916 Sacadura returned to Portugal and begun its instructor pilot career. He developed the "path corrector" which he created to compensate the drift caused by wind. In 1922 Sacadura made the First Air cross from Europe to South Atlantic. In 1923 he proposes himself to make an attempt to the First Air Circumnavigation Journey. He developed all its possible efforts to initiate this journey in March of 1924; however some delays had forced him to postpone the journey. Sacadura received important official medals and prizes, including the PhD Honoris Causa from the Universities of Lisbon and Oporto. In 1924 he died before he could carry out its Circumnavigation Air Journey.
\end{abstract}

\section{Keywords}

Sacadura Cabral, South Atlantic Aerial Crossing, Gago Coutinho, Circumnavigation Flight Attempt

\section{Introduction}

In 1709 Bartholomew of Gusmão presented a petition to King John V of Portugal, begging a privilege for his invention of an airship, in which he expressed the greatest confidence, a lighter-than-air airship design. Since that time, the ideas of aeronautics conceptions were exclusively dominated by lighter-than-air airships which served a great variety of purposes till the $20^{\text {th }}$ Century. In 1909 an aeronautical exhibition was held at Frankfurt. By order of the Ministro do Exército (Minister of Army), Lieutenant Engineering Pedro Fava Ribeiro de Almeida 
was sent to attend that event. Pedro Almeida was a supporter of the military use of balloons. After what he had observed, he returned to Portugal as an absolutely staunch defender of all theories of apparatus heavier than air. During that journey he visited some aero clubs, which led him to assemble a group of friends with the idea to organize a similar association at Portugal. On December $11^{\text {th }} 1909$ with 17 members, mostly Engineering Officers he founded in the Aero Clube de Portugal, with the main purpose to co-ordinate the future Aviation role. The immediate result was the birth of sport aviation at Portugal. In this Country, the airships heavier than air counter the indifference of the majority of the population and the despite of the higher classes by adopting maneuvers for publicity rather than for any useful purpose. However, such maneuvers were decisive in the development of the new means of transportation, whose future value can be foreseen only by a few visionaries. The development of the Aviation in Europe, especially France, where Military Aviation was created in 1909 with the intent to cooperate with the Army, had generated some interest to Portugal, which enthusiastically led Dr. Antonio José de Almeida in 1912 to defend in the Portuguese $1^{\text {st }}$ Republic Parliament, the creation of Military Aviation in Portugal aimed at supporting the Army and the Navy. Amidst the growing enthusiasm that the airplane was awake, it began to appear the first subscriptions to purchase apparatus destined to the Army. In May 1912 an acquisition propose of an Avro 500 biplane was approved, purchased in England. This airplane arrived to Portugal on October $8^{\text {th }} 1912$ and was christened with the name of "República". In August 1912 a Maurice FarmanMF4 biplane was bought in France, christened with the name of "Casta Susana". On September 28 ${ }^{\text {th }} 1912$, Lieutenant Colonel Albino Costa, born at Sever do Vouga, Portugal, naturalized as Brazilian citizen, offered to its Motherland a Deperdussin type B monoplane [1]. On January $28^{\text {th }} 1913$, Portugal was affiliated to the Fédération Aéronautique Internationale-FAI (International Aeronautical Federation). Harnessing this enthusiasm, on February $8^{\text {th }} 1913$ was named a commission of Army and Navy Officers with the purpose to study and consolidate the main bases for the organization of a Flight School with military character and to choose the area as well as the airplanes to acquire. Later that year the Committee presented a report with some recommendations that led to a Law Decree signed by President of the Republic, Dr. Manuel de Arriaga, the Minister of War, General Pereira D'Eça and the Minister of the Navy, Commander Augusto Eduardo Neuparth, dated on $14^{\text {th }}$ May 1914, creating a School of Military Aeronautics. The inclusion of a Marine Aviation section was thought narrowing the options of choice at locations near the Tagus River. The initial recommendation proposed Alverca as a location for the School, but great difficulties have arisen in connection with onerous land expropriations. After was proposed its creation at Vila Nova da Rainha (Figure 1). It was inaugurated in 1916 with the designation of Escola Militar de Aviação [Military Aviation School].

\section{Sacadura Cabral and the Dawn of Portuguese Aviation}

Sacadura Cabral (Figure 2) was born in May $23^{\text {rd }} 1881$ at Celorico da Beira near the Portuguese higher moun-

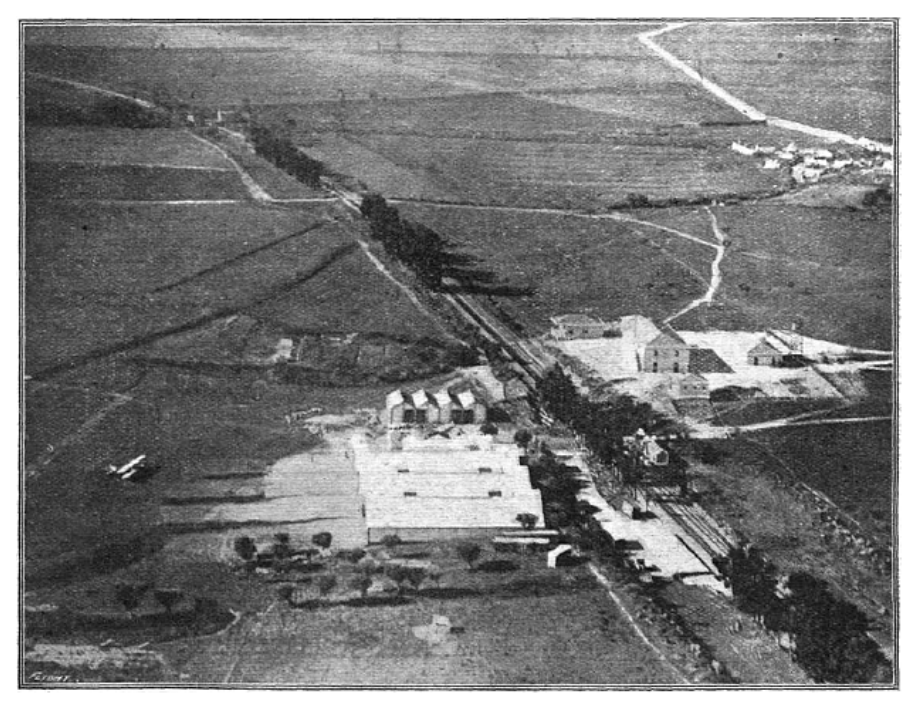

Figure 1. Military Aviation School at Vila Nova da Rainha taken from a height of about 300 meters [1]. 


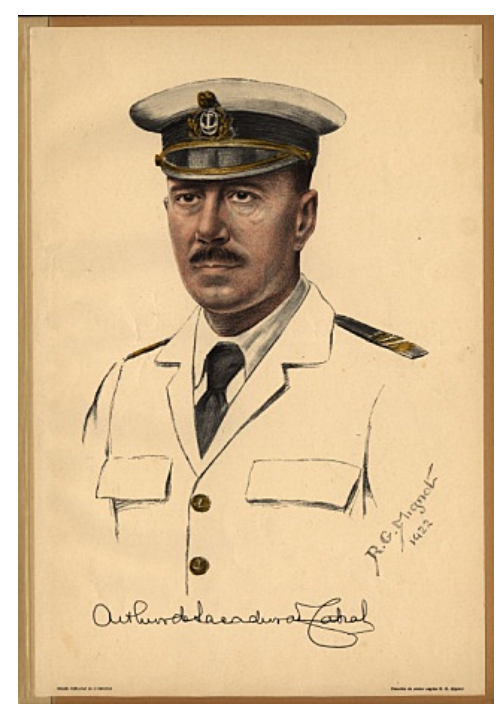

Figure 2. Portrait of Artur de Sacadura Freire de Cabral.

tains (Serra da Estrela) at the center of Portugal. At that time life was quite difficult in the rural areas, and the military career was one of the most promising. So, Sacadura Cabral joined the Portuguese Navy with 16 years of age. In November $10^{\text {th }}$ 1897, he was enlisted as Aspiring. During the studies at the Escola Naval (Naval School) he was the student with the highest ratings among the 35 members of his class. In 1901 he finished the course and embarked on board of the São Gabriel Cruiser to the Divisão Naval de Moçambique (Mozambique Naval Division). In the few years that he had been shipped, always at the Mozambique coast, Sacadura became familiar with the sea services and knew all the ports of that Ultramarine Province. In April $27^{\text {th }} 1903$ he was promoted Second-Lieutenant. In 1905 the Portuguese Government decided to proceed on a thorough survey of the Lourenço Marques Bay, with the aim of the port modernization. Sacadura Cabral was one of the chosen officers to work on this project and had proved that he was a tireless worker and an observer of an incredible accuracy [2]. In cooperation with the Navy colleague Bon de Sousa has produced an excellent hydrographic chart of the Tembe, Umbeluzi and Matola Rivers and of the estuary of the Espírito Santo River. In 1906 and 1907 he worked as a topographer in the rectification of Transvaal and Lourenço Marques border, service in which he has played in competition with the British topographers from the Transvaal. In 1907 a geodetic mission directed by Gago Coutinho came to Mozambique. In carrying out geodetic and geographical missions, Sacadura Cabral and Gago Coutinho worked together since 1907 to 1910 . Sacadura Cabral revealed in this work his skills as a geographer and astronomer, and organizer and in 1910 was appointed Subdirector dos Serviços de Agrimensura de Angola (Sub Director of the Topographic Services of Angola). In September 30 1911 he was promoted First-Lieutenant. In 1912 he participated with Gago Coutinho, in the Barotze Mission, in order to delineate the eastern borders of Angola, which was done in more than 800 kilometers (Figure 3). Barotze was part of the policy of occupation of Central Africa, which is symbolized in the called "Mapa Cor de Rosa" (Pink Map), with opposite interests of Portugal and United Kingdom [3]. In this Mission, the work and authority of Sacadura were daily recognized by the British military engineers who were part of this Mission representing the Rhodesia interests in Central Africa [2]. After this mission, he returned to Portugal in 1915. In 1915, War requirements forced a group of Officers, mostly from the Cavalry, to go abroad, as the only way to achieve their pilot licenses. On August $14^{\text {th }} 1915$, the Portuguese Ordem do Exército (Order of the Army) provided opening positions during 30 days, for Army and Navy Officers in order to start to serve the Country in the Aviation. Eleven Officers had competed and were all accepted. Thus, Cifka Duarte, Carlos Beja, Francisco Aragão and Salgueiro Valente were sent to the Signal Corps Aviation School, San Diego, California, United States of America. António Maia, Lelo Portela and Oscar Torres were sent the Ruffy-Baumann School, Hendon, and later to the Military School of Northold, both at United Kingdom. Santos Leite, António Caseiro and Sacadura Cabral were sent to the Centre d'Aviation Militaire de Chartres, France. On November $11^{\text {th }} 1915$ Sacadura Cabral held its first flight as a passenger and on the January $16^{\text {th }} 1916$ he made its first flight as a pilot. On March $7^{\text {th }}$ he made its first license examination and in 


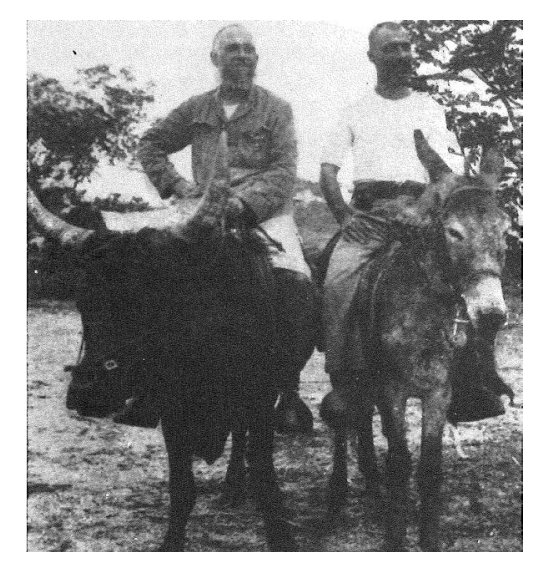

Figure 3. Gago Coutinho and Sacadura Cabral at the Angola/Barotze border, 1913 [8].

March $9^{\text {th }}$ obtained the pilot license in a Maurice Farman airplane type. During his instruction he made 222 flights with a total flight time of 28 hours and 57 minutes and was considered trés bon pilot (very good pilotsee Figure 4). After the pilot license in this School and still in France, he went to the École de l'Aviation Maritime de Saint-Raphael (Maritime Aviation Scholl of Saint Raphael), and made a specialization in seaplanes, with a total flight time of 8 hours and 30 minutes [2]. He also attended at various training Schools and made a specialization in faster airplanes flying the Blériot and Caudron G3 models in the École d'Aviation de Buc (Aviation School of Buc). In August of 1916 Sacadura finished his apprenticeship at France and returned to Portugal. At that time the Escola Militar de Aviação was being organized at Vila Nova da Rainha, and Sacadura Cabral was incorporated as a pilot instructor (Figure 5). During the time that he served in that school, he piloted several aircraft types. However, the Government decided to send a Squadron to Mozambique to cooperate with the Army in the region of Niassa. In actions of war, Germany had invaded Portuguese territory at Mozambique. In order to defend this region, Sacadura was sent on a mission to France to acquire all the equipment needed to equip this unit that was the first Portuguese Aviation Unit. In September $28^{\text {th }} 1917$, Portugal created by Law Decree (Decreto-Lei $n^{\circ}$ 3395, de 28 de Setembro de 1917) the Serviço de Aviação da Armada (Navy Aviation Service), from which Sacadura was the inspiration and the driving force [4]. In 1918 he was appointed Director dos Serviços da Aeronáutica Naval (Naval and Air Force Director) where he studies and organized the Aviação Marítima (Navy Aviation). Later he was appointed Comandante da Esquadrilha Aérea da Base Naval de Lisboa (Commander of the Air Squadron of the Naval Base of Lisbon). In April $25^{\text {th }} 1918$ he was promoted LieutenantCommander. In 1919 he was appointed to be part of the Commission in charge to study an air navigation implementation plan. In May $26^{\text {th }} 1919$, one day before the arrival of Lieutenant Albert C. Read to Lisbon, (Sacadura had the opportunity to meet Albert C. Read and to obtain acquaintance for subjects related to the Intercontinental Journeys-see Figure 6) Sacadura handed a document to the Minister of the Navy in which he proposes himself to hold the Crossing Lisbon to Rio de Janeiro with the purpose of the progress of Portuguese Aviation and as a way of strengthen the ties of friendship between Portugal and Brazil. A few days after the first transatlantic flight of the American NC-4 flying boat, during the official visit of the President of Brazil to Lisbon, the Portuguese and Brazilian governments agreed to prepare a joint crossing of the South Atlantic between Lisbon and Rio de Janeiro as a way of strengthen the ties of friendship between the two countries reflecting the affinities of language, thoughts and feelings [5]. The Ministry of Navy in accordance with the document received from the Government on June $6^{\text {th }} 1919$ (Portaria de 6 de Junho de 1919), instructed Sacadura to organize the attempt of Lisbon-Rio de Janeiro crossing. The same Ministry also managed that Foreign Affairs had appointed Sacadura as Adido Aeronáutico [Aeronautical Attaché] near the Portugueses Legacies at London, Paris and Washington. This appointment allowed Sacadura to have access to official agencies and aircraft manufacturers in such countries. Yet in order to choose the aircrafts, he was sent to England and France. In June $15^{\text {th }} 1919$ Sacadura had already delivered documents to all manufacturers enterprises, (Italy, Societá per lo Svilupo dell' Aviazone; France, Latham and Levy-Blanchard; United Kingdom, Fairey Aviation Cy, Handley Page, Vickers, Vimy, Felixtowe-Fury, Blackburn Aeroplane, English Electric Cy and Short; United States of America, Curtiss), revealing the intention of crossing the Atlantic and asked for information about the most suitable aircraft types 


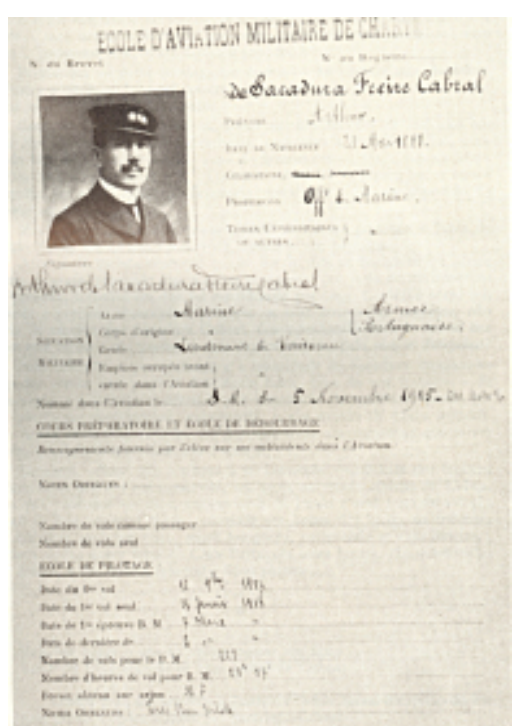

Figure 4. Page bulletin of the Centre d'Aviation Militaire de Chartres [Military Aviation Center] [2].

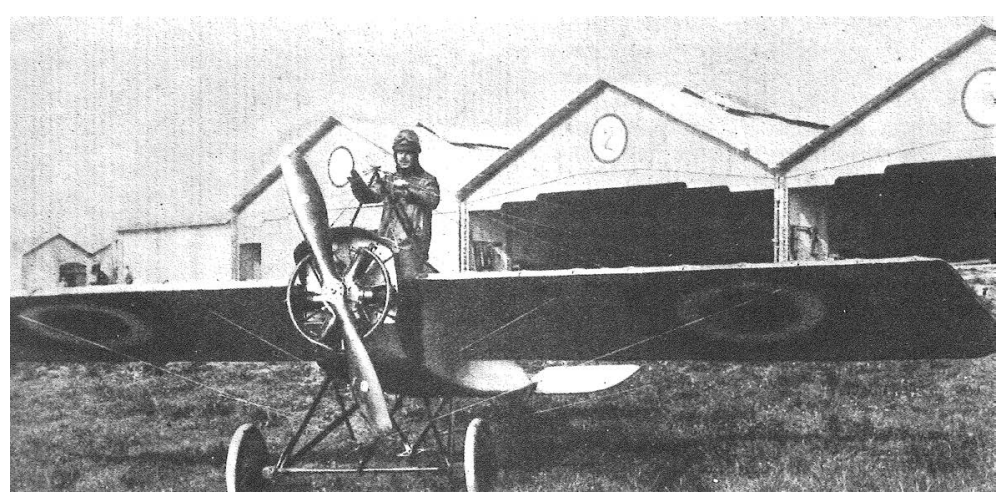

Figure 5. Sacadura Cabral in aMorane Saulnier airplane at Vila Nova da Rainha, 1917 [1].

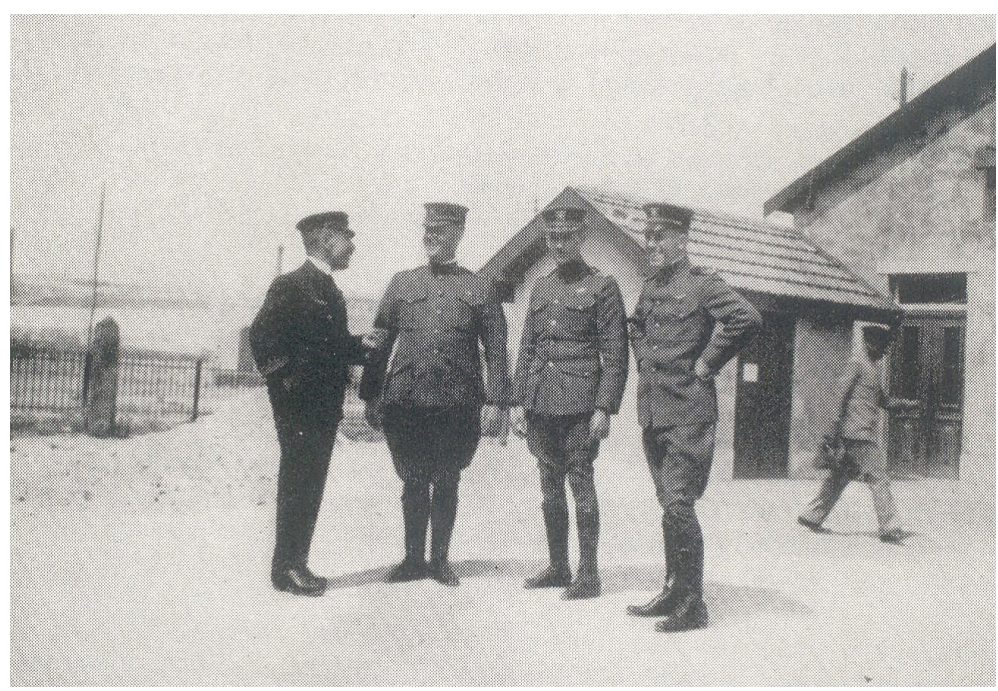

Figure 6. Sacadura Cabral with Lieutenant Albert C. Read and part of its team at Bom Sucesso Naval Aviation Center [2]. 
[2]. He presented an advanced plan report of the crossing attempt which reported some doubts about the possible accuracy of navigation at the time. The first obstacle was how to find small islands after a long journey flying over the sea (find S. Pedro Rock, nearly 200 meters length and 18 meters height after 1260 nautical miles) and the second obstacle was to choose the type of aircraft to be used, since the manufactures had no airplanes with long range capability for deliver, a reason that had to suspend the project of the Atlantic Crossing, postponed to a better opportunity. Completely aware of the navigation obstacle, Sacadura had encouraged Gago Coutinho to devote himself to the airnavigation problem, which led to the development of the artificial bubble sextant. This new instrument was called "precision sextant" and used an artificial horizon line which was defined with the help of a water bubble [6]-[11] (Figure 7). To complement the celestial navigation, Sacadura deepened himself in air navigation knowledge. He studied a new device to compensate the drift caused by wind, which became known as the "path corrector". This device was presented in the Premier Congrés International de la Navigation Aérienne, (First International Congress of Aerial Navigation), at Paris on November $15^{\text {th }}$ to $25^{\text {th }}$ of 1921 [2]. These two navigation instruments were tested during short flights between July $21^{\text {st }} 1920$ and January $21^{\text {st }} 1921$. The use of these instruments was complemented by the use of Auss tables, or with the collection of Houel tables. Parallel to the Portugal-Brazil voyage organization, Sacaduzra carried out his duties in the Naval Aviation. In 1920 Sacadura was appointed to serve on the Comissão Mista de Aeronáutica. In the same year, he and Pedro Rosado went to Calshot, Southampton, United Kingdom to acquire two hydroplanes F3 Felixtowe (with 4017 and 4018 numbers). In the way back to Portugal they stopped at Brest and Ferrol. It was the second time that the Biscay Bay was crossed by air (the first was Albert C. Read). They arrived at Lisbon on May $15^{\text {th }} 1920$. These seaplanes were then prepared for the Lisbon-Funchal voyage. In March $22^{\text {nd }} 1921$ with the help of the precision instruments and with Gago Coutinho, Ortins de Bettencourt and Roger Soubiran on board, Sacadura made an experimental flight from Lisbon to Madeira (520 nautical miles-Figure 8) [12]. Above all, he sought to prove that air navigation could be just as accurately pursued as sea navigation, by deploying sextants and other available astronomical devices.
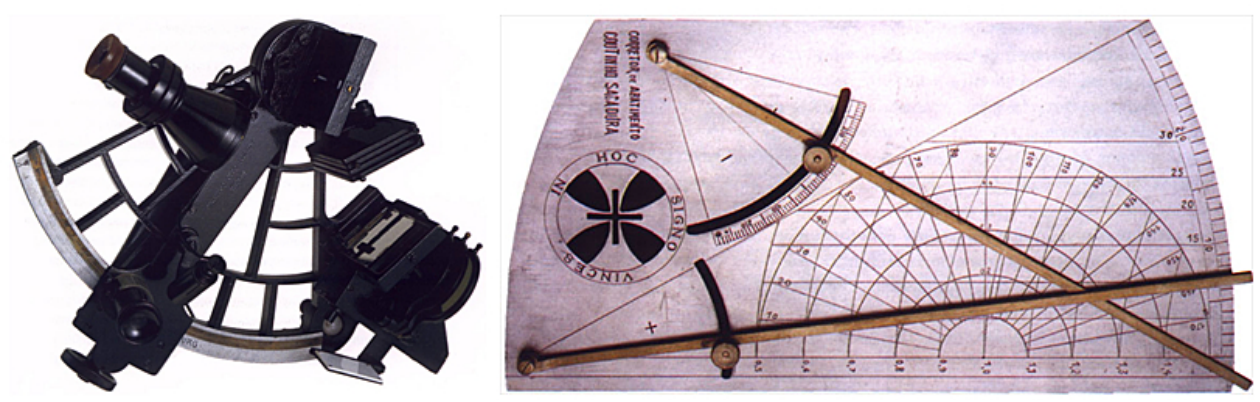

Figure 7. Precision sextant developed by Coutinho and path corrector developed by Gago Coutinho and Sacadura Cabral.

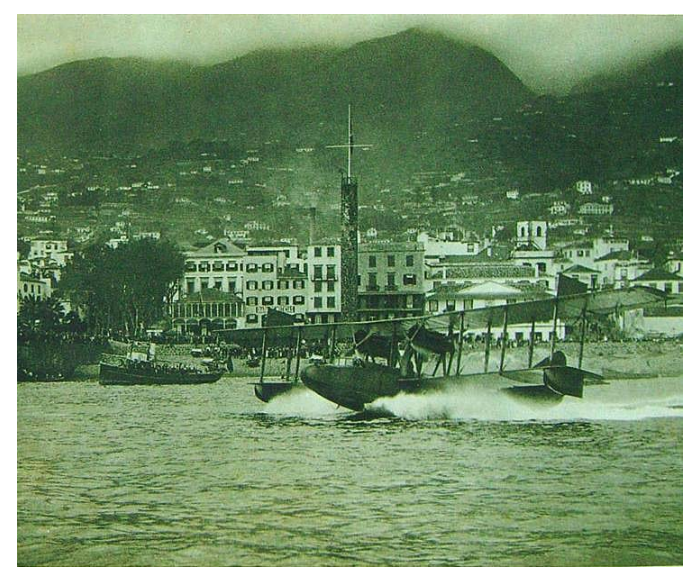

Figure 8. The F3-4018 take-off at Funchal [12]. 
The trajectory should be a perfect straight line, and to verify the position of the aircraft three ships were used to control its position. The result was a complete success voyage with 7 hours and 30 minutes of duration and he started to believe that they were prepared to initiate the transatlantic flight from Lisbon, Portugal to Rio de Janeiro, Brazil, through Cape Verde and Fernando de Noronha Islands. In July 1921, Sacadura return to insist near the Minister of Navy in a way to proceed the plane of Lisbon-Rio de Janeiro crossing voyage. After the agreement of the Minister, Sacadura returned once more to analyze the types of aircraft available to date. Of all the airplanes, the most efficient (in terms of speed and endurance) were those that could land, yet the lack of airfields on the Cape Verde and Fernando Noronha Islands eliminated this option. During the journey studies, Sacadura received the information that the Brazilian Aviation could not come to follow in his proposed project as Brazil sincerely had desired. The solution was the seaplane and the budget cuts inclined to favor a single-engine seaplane.In September $4^{\text {th }}$ 1921, Sacadura went to England to contact the Fairey enterprise manufacturer of the model chosen by him, a Fairey III-D. This aircraft was equipped with a Rolls Royce, the same as used on the Lisbon-Funchal voyage. This fact was decisive on his choice. In addition the manufacturer had already ready plans for the Sacadura seaplane sought, the modified F III-D model. Sacadura and his team followed the construction and all modifications of the aircraft, which after difficult experiences and adjustments, was ready at the end of 1921. The purchase contract for the aircraft included two more serial seaplanes FIII-D.The airplane was sent to Portugal disassembled in January 1922. The assembly was made by the staff of the Naval Aviation Center. During the time that Sacadura was in the United Kingdom, witnessing the experiences of the plane Sacadura Cabral wrote two letters to Gago Coutinho (October $16^{\text {th }} 1921$ and January $8^{\text {th }} 1922$ ) envisaged the possibility in the future to ask his own Navy resignation if there were no authorization to make the Lisbon-Rio de Janeiro voyage. He withdrew from this idea, thanks to the courageous Navy Minister Victor Hugo de Azevedo Coutinho that enabled the voyage [2]. Sacadura returned from England only on March $6^{\text {th }} 1922$. When he arrived to Portugal, he presented himself to the Navy Minister and provided him all information concerning the attempt of the Lisbon-Rio de Janeiro voyage. As a result he received an order from the Minister to prepare the seaplane urgently and to start the journey as soon as possible. To support the aviators the Portuguese Navy provided four ships: "Républica", "5 de Outubro", "Bengo" and at the final phase of the voyage, the "Carvalho de Araújo". The following next two weeks were very intense for the experienced pilot of the mission, Sacadura Cabral and for the navigator and observer Gago Coutinho. The flight had to be carried out in several stages as a result of the aircraft specifications and limitations, and several problems due to weather and sea conditions. A first major problem happened when trying to land at Penedos (near the Brazilian Coast) where the ship República was planned to refuel the hydroplane "Lusitania" and one of the floats was destroyed bythe crest of a wave and the hydroplane tilted and sank soon thereafter. The Portuguese government decided to help Gago Coutinho and Sacadura Cabral, and sent another Fairey hydroplane. After some problems to unload the hydroplane they finally continued their journey, but later they had serious engine problems that added to heavy rains forced them to sea land. Before they could re-start the journey the floats started to sank and they had to be rescued by a British freighter. On the $5^{\text {th }}$ of June they received a Fairey F III-D, called "Santa Cruz" that was used without further problems to travel from Fernão de Noronha to Recife. Finally they flew to several cities in the Brazilian coast, and then reached Rio de Janeiro on the $17^{\text {th }}$ June of 1922.

For the first time in the history of the aviation the crossing of the South Atlantic had been achieved and using an instrument that enabled an airplane's position to be determined by astronomic navigation when flying out of sight of land. Figure 9 illustrates a propaganda pamphlet of the First South Atlantic Aerial Crossing. During their stay at Brazil, Coutinho and Cabral received great honors some of them counting with the president of Brazil at the time (Figure 10). On April 27 $7^{\text {th }} 1922$, Cabral was promoted Commander with distinction [13]. Between 1920 and 1923 Sacadura made nine Conferences at Portugal Brazil, France (Figure 11) and United Kingdom. After the Lisbon-Rio de Janeiro cross, Sacadura proposed himself to conceive and organize an air circumnavigation journey, which he admitted that had to be firstly done by the Portuguese, not only for historical reasons (repeat Fernão de Magalhães, 1480-1521), as well as of foreign and domestic reasons policy. First he gathered the representatives of the Portugal's largest newspapers and correspondents of the Brazilian Press where he expressed the feasibility and political and historical advantages for Portugal. Days later again with the Press he urged the Country to support this initiative by National Subscriptions. Besides having sent its report to the Navy Minister, Sacadura asked for an audience with the deputies and senators of the Congresso da Républica. The project was exposed and although not fully accepted had revealed that the majority of deputies and senators had agreed. Sacadura appealed to the Brazilian Aeronautical Authorities to authorize a team to accompany 


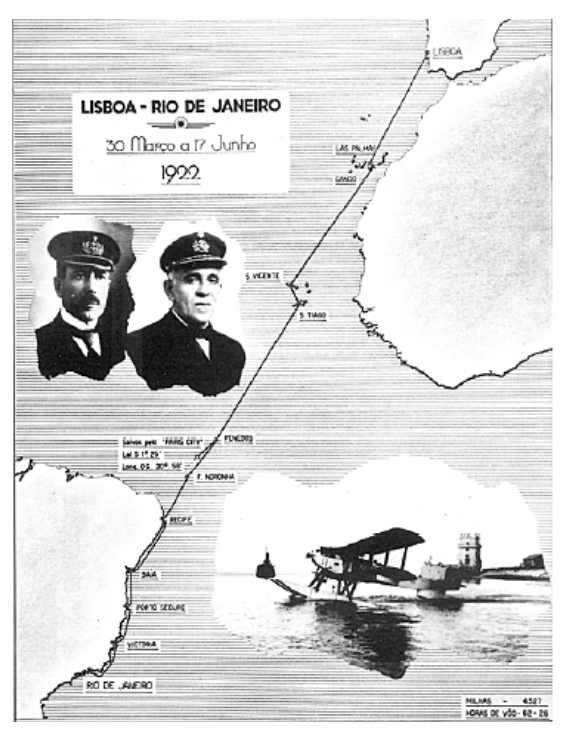

Figure 9. Propaganda of the First Flight Crossing from Europe to South Atlantic (Lisbon-Rio de Janeiro [12].

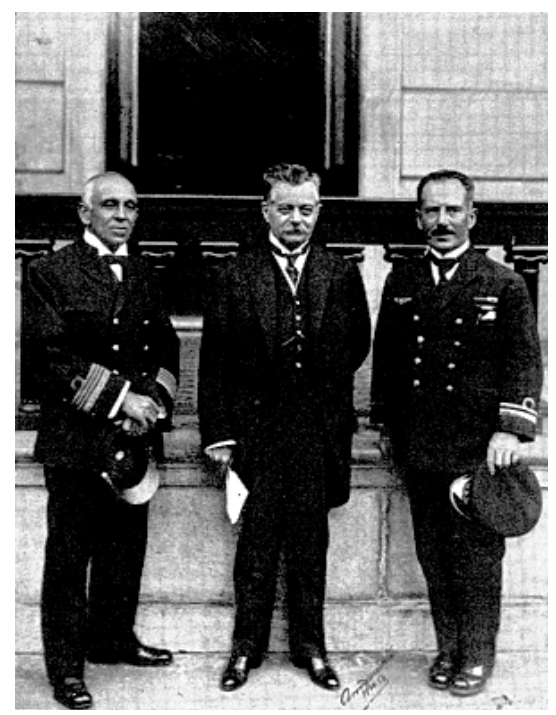

Figure 10. Sacadura Cabral and Gago Coutinho with the Brazilian President Epitácio Pessoa [2].

him on the trip Around the World as he had already done in the First Cross South Atlantic journey. Since Coutinho was travelling to Brazil, he asked him to carry the official invitation to the possible collaboration of Brazilian Aviation. Apart from the preparation and organization work of the trip, Sacadura almost daily had to respond through the Press, to all the expressed opinions by their opponents. They argued due to financial or personal problems. Hardly there were technical reasons to discuss the report. One of the main arguments of his opponents was related with the two ships that Sacadura asked to the Navy for supporting the journey. Opponents argued that such vessels could not be used to support this trip because that was not of military character. Sacadura managed to get the money for the purchase of five Fokker aircraft chosen for the circumnavigation voyage. However the Brazilian Aviation argued that was experiencing severe austerity measures that time and cannot reimburse the trip. Portugal also declared that the two asked support ships could be not available for the journey. However the discussions and delays from the Despachos (Orders) exceeded the previously set date for the beginning of the trip. The schedule was designed in harmony with the weather conditions of the regions that would 


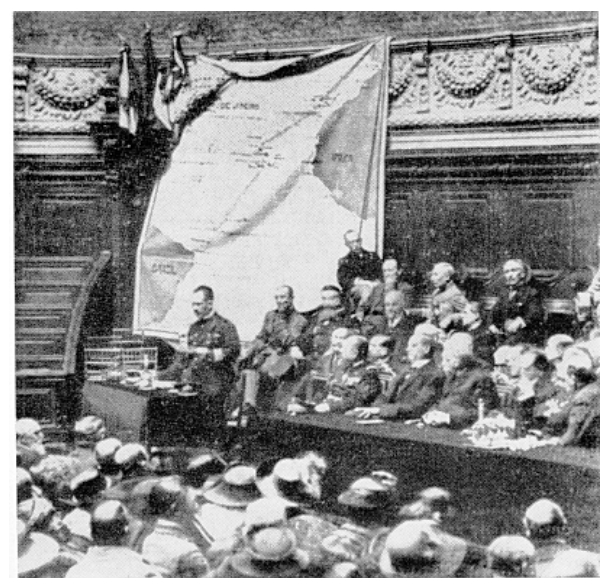

Figure 11. Sacadura at Sorbonne, France, 1923, exposing the First Crossing from Europe to Atlantic South [2].

be over flown. Sacadura easily understood that a single plane with the same engine would not be able to give success to this trip. At the time there was no engine that worked so many hours without compensation or review. During the trip, the aircraft used would be exposed to weather conditions. Wind, rain, heat and cold would contribute to the destruction of the apparatus, or at least to reduce their flight quality. The trip was organized to be made in the direction of prevailing winds (west to east) and comprised three legs each to be flown at three different airplanes. The first leg was from Portugal to Japan, (Lisbon/Alger, Alger/Malta, Malta/Crete, Crete/ Aleppo, Aleppo/Basra, Basra/Bandar Abbas, Bandar Abbas/ Karachi, Karachi/Delhi, Delhi/Allahabad, Allahabad/Calcutta, Calcutta/Rangoon, Rangoon/Bangkok, Bangkok/Saigon, Saigon/Turan, Turan/Macau, Macau/ Fuchau, Fuchau/Xangai, Xangai/Nagasaki, Nagasaki/Kobe and Kobe/Yokohama). Each sector of this trip was ranging between 330 and 660 miles and the first leg had nearly 9870 miles. The second leg was from Japan to Newfoundland, (Yokohama/Akashi, Akashi/Simushir, Simushir/Petropavlovsk, Petropavlovsk/Attu Island, Attu Island/Atka Island, Atka Island/Kodiak, Kodiak/Sitka, Sitka/Vancouver, Vancouver/Dumore, Dumore/Winnipeg, Winnipeg/Sault Saint Marie, Sault Saint Marie/Quebec, Quebec/Newcastle and Newcastle/Saint John). This leg has nearly 7580 miles, with each trip varying between 300 and 650 miles. The third leg was from Newfoundland to Portugal, (Saint John/Faial, Faial/Ponta Delgada, and Ponta Delgada/Lisbon). This leg was nearly 2140 miles, each trip ranging between 160 and 1200 miles. The total trip would include approximately 19,590 miles, requiring approximately 280 flight hours at an average speed of 70 miles an hour. For the first leg the airplane would had to fly about 141 hours, which would mean an engine change to be provided at Rangoon, after flying 87 hours (Figure 12).

The second airplane would fly about 109 hours of flight with an engine change planned at Vancouver, provided to cross Canada in good conditions. The third airplane would fly through 31 hours. It would be impossible to predict where there might be a failure, or even where it would be necessary to replace any part of the engine or of the airplane. And it would equally be problematic to find fuel or oil in certain regions of the World, as in the Kuril and Aleutian Islands. These Islands were inhabited by hunters only at Summer time. Sacadura thought to make the crossing of the Pacific accompanied by a ship that could take material or human resources that allowed eventually its presence at the point where they might need between a determinate time periods. This ship could be a merchant ship with about 2000 tons and had to have large basements. One of the basements would be to transport store material and the remaining basements were to fill of coal in order to allow a wide range. Of all the merchant ships known, it would be chosen the one that best suite those requirements. The ship crew would be increased with Aviation specialists. The Brazilian Government would be invited to collaborate on this trip in terms of complete equality. Thus aerial circumnavigation of the trip would be tried in a fair and perfect harmony, by the Aviação Marítima Brasileira and by the Aviação Marítima Portuguesa. Each Country should delegate one member to study and organize the trip. Each Country should provide a group of pilots and mechanics and at least three airplanes, with the possibility of three more in reserve. Each Navy should send a transport ship, which should be provided with great range TSF, for long-distance communications. Independently from any other 


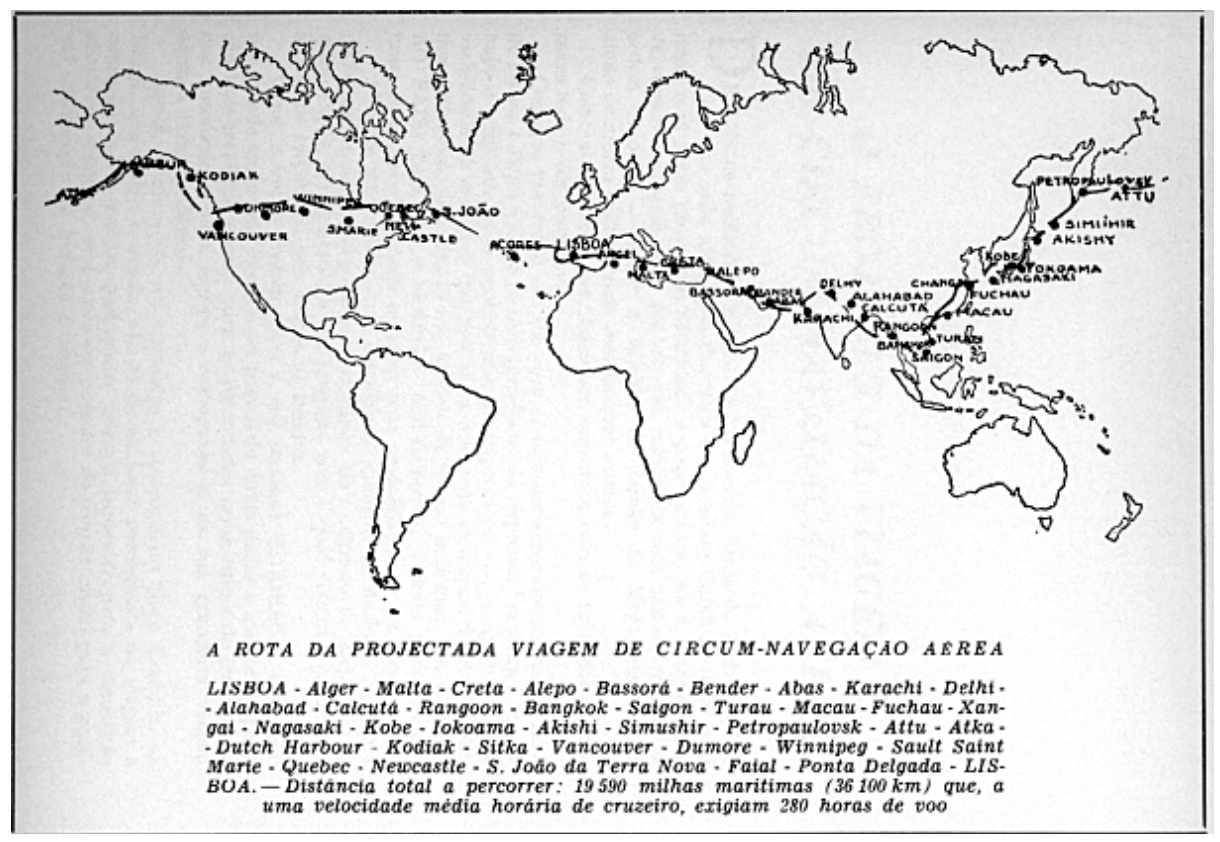

Figure 12. Aerial Circumnavigation Journey idealized by Commander Sacadura Cabral to be started at March 1924 [2].

subjects, Sacadura studied how to get the best weather system throughout the entire journey. Examining the Winds Chart, he found that in the early spring, the trajectory of low pressure center coming out of Canada headed to the Mediterranean and then moved to North, crossing the British Islands and Germany at the summer, which gives generally good weather conditions at the Mediterranean, with the predominance of westerly winds. At the Indian Ocean in May, the monsoon starts from $S W$, and sometimes was accompanied by torrential rains. This monsoon was preceded in April by light winds indicate the turn of the monsoon from $N E$ to $S W$. After May at Japan it begins the rainy season with predominant winds from the $S W$. In the Aleutian Islands at summer time the storms become rare and the wind prevalence was from $S W$. There were fogs often seen at this region, generated by winds from $S W$ and by the Kurosiwo warm sea current (form Japan) that extends up to these Islands. Both at Canada and at Atlantic Ocean and throughout all the year, the general predominance of winds was from the west quadrant, however at summer time the frequency and intensity of storms diminished considerably. The almost total lack of local resources and the deficiency of telegraphic communications that could allow the weather conditions knowledge made Sacadura thought that it would be required the presence of two more vessels: one vessel at the starting point (Japan) and another vessel at the arrival point (Vancouver, where Sacadura knew the existence of dense fogs at the summer time). From all that Sacadura exhibited, he realized that the journey should start at March in order to across India at April. It would be also desirable to arrive to Japan at May and fly over the Aleutian Islands between May and June in order to arrive at Newfoundland at July. The Atlantic crossing should be between the favorable period of July and August. Whole the entire trip was designed so that it could be possible to change the airplanes: with wheels or floats. For the wheels case, the airplane would fly by Spain, southern France, Italy, Greece, and Crete and then by the prior route to Rangoon, where the wheels would be replaced by floats until Vancouver. From Vancouver to Newfoundland wheels would be used again. From Newfoundland to Portugal it could be used a seaplane. Whatever the airplane type to be chosen it will have to meet the following requirements: Amphibian apparatus with at least $30 \mathrm{~cm}$ of distance to the ground when the wheels were down or apparatus that could use wheels or floats, with at least $30 \mathrm{~cm}$ of distance to the ground or to the sea water. All the apparatus would have to be equipped with Rolls or Napier engine. The preference would be Rolls. The maximum payloads were 10.5 pounds per square foot, 19 pounds per horse power. The apparatus would also be equipped with fuel tanks with capacity for 230 gallons of gasoline, with a visible level and with gravity tank. These tanks would have to be inside the fuselage. Sacadura preference was that the airplanes were equipped with only one reservoir and one gravity tank. The gasoline system with gravity tank should have two pumps driven either by the progress way or by the hand and should have a high debt clock system. 
The airplane's hull and floats should all be compartmentalized and watertight. The aircrafts will prove its tightness, during 48 hours in water with its full load and no water inside or on floats should be found. With its total load the consumption of any airplane should be less than 20 gallons of gasoline per hour. The plane should reach a cruising speed of at least 70 miles per hour and should be able to take off from the water with its full load and with a wind speed of less than 8 knots. The aircraft should be tested with full load and empty load with the registration of the guaranteed plafonds for each case. The total load should consist of: three-man crew, 500 pounds; 230 gallons of gasoline, 1650 pounds; 12 gallons of oil, 110 pounds; extras and spares, 160 pounds; equipment and onboard instruments, radiator water and a reserve deposit of 2 gallons. Sacadura foresaw the possibility of fatal accidents during such a long trip. This led him to plan the trip with reserve pilots and mechanics. The mentoring of all staff who were connected to the trip was that once begun, would be completed at all costs. Sacadura was also several times criticized that the journey would become very expensive. He replied that the total expenditure could not be exaggerated. The acquisition of aviation material could be made with 30,000 sterling pounds. The accompaniment ship will consume daily 20 tons of coal. The price per ton was 36 shillings [2]. Assuming 150 days of shipping (about 36,000 miles - 10 miles per hour) and money spent with lubricants, the spent will be of 6000 sterling pounds. For six months, the total expenses with the addition of the ship crew would be 10,500 sterling pounds. The total expense would be nearly 46,500 sterling pounds. The amount for the purchase of aircraft (30,000 pounds sterling) was still achieved by the Aviação Marítima with the concession contract of the commemorative stamps of the $1^{\text {st }}$ Air Crossing of the South Atlantic. This amount should be considered as a reserve for the eventuality of having to be used in cases of extreme need. Sacadura then thought of asking the Country for National Subscriptions (Letters to the Diário de Notícias-Lisbon 17, 20 and 23 of June 1923). In those letters Sacadura exposed to the Country that he needs the money to make possible the journey attempt. Meanwhile Sacadura traveled to United Kingdom and to Netherlands in search for airplanes that were able to meet all the requirements that he had idealized. He arrived at Portugal in August of 1923 and reported that had been ordered five Fokker aircrafts (see Figure 13): four of them had a Rolls 360 hp engine and a fuel tank capacity for 265 gallons of gasoline. Each of these airplanes had capacity to fly during 13 hours. The other airplane had an engine of $460 \mathrm{hp}$. Napier and a fuel tank with a capacity of 400 gallons, and had capacity to fly nearly 20 hours. The cruising speed of all these airplanes was 75 miles per hour. These aircrafts were equipped with floats, but could be modified to use wheels and their construction should be finished on December $31^{\text {st }}$ of 1923. The Fokker manufacturer enthusiastically will send an assembly specialist on their behalf to follow the entire journey on a ship and the Napier manufacturer would send a mechanic to Newfoundland to review the equipment that would fly the Atlantic. However, the Portuguese government had denied the coal supply for the future support vessel previously provided for the journey. The ship could not transport the acquired aircrafts from the Netherlands to Portugal. Sacadura ruled that he himself would be the transporter of the first aircraft. On the afternoon of August $30^{\text {th }} 1923$ he landed at Amadora, where the Minister of the Navy was waiting for him. In that day the press asked Sacadura if he still wanted to make the circumnavigation journey. Sacadura replied: "Yes, but for that I need 30,000 sterling pounds. It's sad to say, but it must be confessed, without money nothing

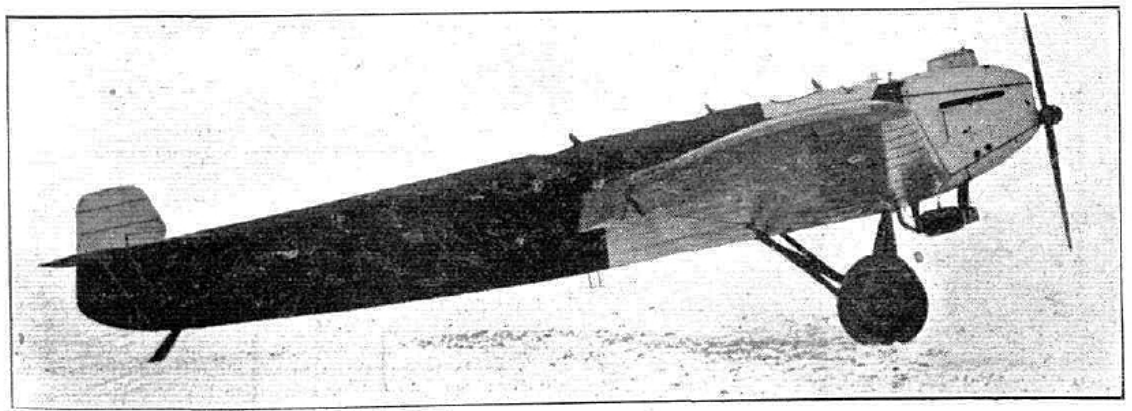

THE FOKKER T-III MONOPLANE: The machine shown above is a three-seater low-wing cantilever monoplane, which is fitted with either a 450 h.p. Napier "Lion" or a 360 h.p. Rolls-Royce "Eagle." Several of this type have been-or are being - constructed for the Portuguese Government, and it was the type of machine which Admiral Continho and Commdr. Sacadura Cabral selected for their world-flight. If required, the wheels may be replaced by two floats. Its span is $69 \mathrm{ft}$. 6 ins.; overall length, $42 \mathrm{ft}$. 6 ins.; wing area, 775 sq. ft. ; and speed 111.6 m.p.h.

Figure 13. Fokker T-III monoplane chosen by Commander Sacadura Cabral for the Circumnavigation Attempt [15]. 
can be done...” On that day Sacadura reported to the Portuguese media that in 1924 it would be attempted a similar journey by three British pilots groups and that they intend to start the journey also at March. Only one the five Fokker aircrafts was delivered disassembled to Portugal. Because of all the difficulties and expressed unwillingness Sacadura was forced to give up of the circumnavigation journey at least during the year 1924. Once again, Sacadura sent a letter to the Director of the Diário de Notícias (letter dated January $5^{\text {th }}$ 1924) to be published in that newspaper, where he summarily explained the result to the journey failure. He explained where the money was applied and even gave assurances to all underwriters that after making the journey, the money would be returned to the investors. On January $7^{\text {th }} 1924$, Sacadura explained that if at March 1925 he had all the elements considered important for the journey, he would proceed with another attempt. While living petty rivalries at Portugal from March $17^{\text {th }}$ to September $28^{\text {th }} 1924$, four teams of American navigators held the Air Circumnavigation Journey [2].

In 1924, convinced that the Government did not correspond to the effort undertaken by him to the efficiency of Maritime Aviation, Sacadura submitted his resignation as a Naval Officer, a request which was refused. Sacadura, with money from their compatriots and friends at Portugal and Brazil had bought five aircrafts. Portugal had no expenses. He could not admit that those airplanes stay housed at the hangars. In 1924, a PortugueseFrench financial group presented to Portugal the establishment of aircraft carriers for a commercial purpose "Convention", between Continental and Ultramarine Portuguese Territories and France. Sacadura was appointed to study the proposal made to the government. He realized that the project had not sufficient warranties to prevent the Country's interests and wrote again to the Diário de Notícias (letter dated May $14^{\text {th }} 1923$ ) to explain in detail to the Portuguese people that the convention would be painful to the Portugal's interests. The Spanish aviation had already shown interest in collaborating with the Portuguese Aviation. Sacadura devised that the Fokker airplanes could be used for this purpose. The Sacadura's main idea was to use two airplanes twice a week between Lisbon and Madrid to carry passengers and mail. The first travel came to be made in five hours and was made already with the purpose to serve as a test for future larger projects. With the most powerful purchased airplane that, Sacadura wanted to make the Portugal/India journey following the route of Vasco da Gama (India Sea route discovery at 1497-1499), nearly 3000 miles route. On September $17^{\text {th }} 1924$ the Portuguese press once again asked Sacadura about a new attempt of the Portuguese aviators attempt to realize the air travel circumnavigation." If we put the benefits that can result from such a journey in a balance dish and if we put all the burden of money on the other balance dish it was easy to verify if from this journey we would obtained any practical result"... "Anyway I am willing to make all the journeys wanted by the Portuguese. Without money no aircraft will leave the hangar..." On November $15^{\text {th }} 1924$, two months after these words, he died somewhere at the English Channel (wreckage was found on November $18^{\text {th }}$ at $50^{\circ} 37^{\prime} \mathrm{N}, 1^{\circ} 10^{\prime} \mathrm{E}$ ), while piloting a Fokker 4146 from Amsterdam to Lisbon [14], one of five planes that had been acquired by public subscription and that would be used in the air travel to India as a beginning of a circumnavigation journey. The corpse was never found. The sea kept for always the body of a Great Portuguese Citizen and so ended the petty discussions about a grand project, which if had been held, from all points of view will have revealed to be of the greatest interest to Portugal and to the Portuguese Aviation [2]. Santos Dumont, Sacadura Cabral and Gago Coutinho were friends and shared also aeronautical knowledge; when Dumont became aware of Cabral's disappearance, he wrote a letter to Coutinho, expressing his feelings (Figure 14).

Thanks to the intelligence and value of Sacadura Cabral and Gago Coutinho, Portugal had in his own hands "the keys of the North and South Atlantic". With the time evolution, the strategic triangle "Lisbon-Azores-Cape Verde" had the highest importance, both at War and Peace time. In Peace-time all the commercial ships could found the necessary supplies for their routes at St. Vincent (Cape Verde). In the First World War, the United States established an Aero-Naval Base at Ponta Delgada (Azores). In the Second World War, the Lajes Air Force Base (Azores) was of central importance. The Faculties of Sciences of the Universities of Lisbon and Oporto, based on the scientific value of the instruments and methods created at Portugal for air navigation by Gago Coutinho and Sacadura Cabral, gave to them the degree of Honoris Causa Doctors, which was delivered to Sacadura with the highest brightness and splendor solemn sessions.

Commander Sacadura Cabral received the highest levels of national and international tributes (Figure 15). His Portuguese Military tribute included several insignias: The "Grã-cruz da Ordem Militar da Torre, Espada, Valor, Lealdade eMérito"; the "Oficial da Ordem Militar da Torre, Espada, Valor, Lealdade e Mérito"; the "Grã-cruz da Ordem Militar de Avis"; the "Grã-cruz daOrdem Militar de Santiago da Espada"; the "Medalha de Ouro dos Bons Serviços"; the "Medalha de Comportamento Exemplar"; the "Placa de Honra da Cruz 


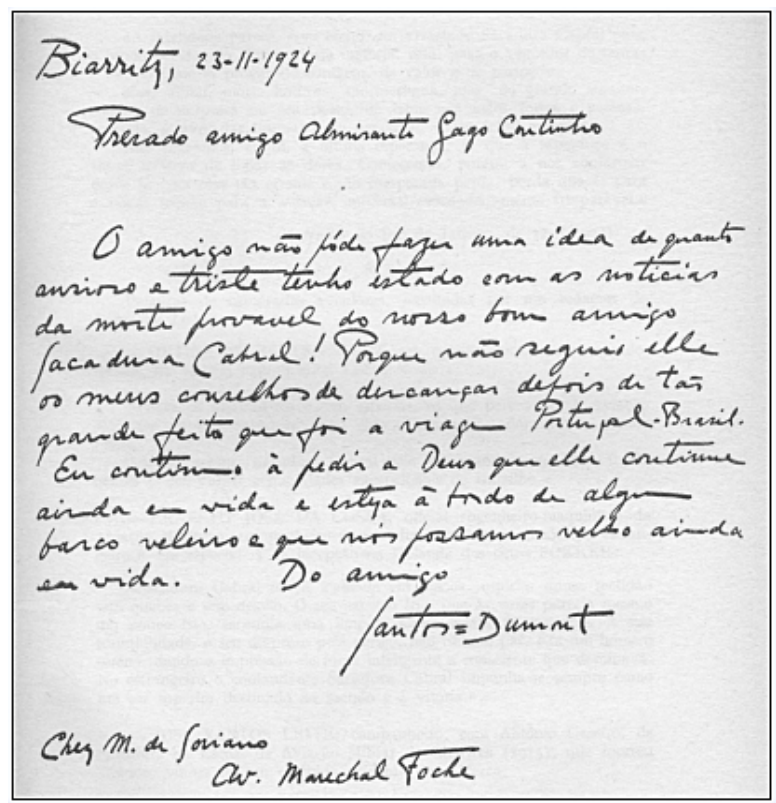

Figure 14. Letter from Santos Dumont to Gago Coutinho expressing his thoughts about Sacadura's accident [2].

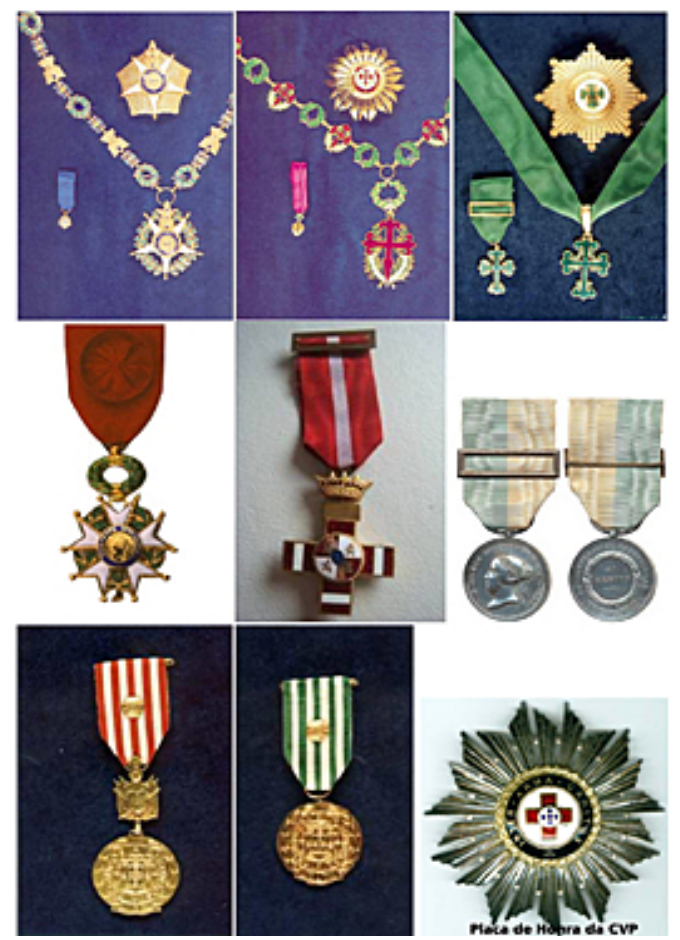

Figure 15. Portuguese and Foreign Honoristic Insignias given to Sacadura Cabral: On top, from left to right: The "Grand Cross of the Ordem Militar da Torre, Espada, Valor, Lealdade e Mérito"; the "Grand Cross of Ordem Militar de Avis"; and the "Grand Cross of the Ordem Militar de Santiago da Espada"; on the meddle: the "Commander Cross of the Legion d'Honneur"-France; the "Grand Cross of the Militar Merit"-Spain; and the "Medalha de Prata de Prémio e Distinção ao Mérito"-the unique Portuguese Monarchy Insignia which was allowed and granted by the Republican Regime; at the bottom: the "Medalha de Ouro dos Bons Serviços"; the "Medalha de Comportamento Exemplar"; and the "Placa de Honra da Cruz Vermelha". 
Vermelha" and the "Medalha de Prata de Prémio e Distinção ao Mérito" the unique Monarchy Insignia which was allowed and granted by the Republican regime. His Foreign Military Tribute included the insignias of the "Commandeur de la Légion d'Honneur", from France and the "Gran Cruz del Mérito Militar" from Spain. In 1917 he was laureate "for zeal and proficiency showed when in charge of acquiring the aviation material in France for the Esquadrilha de Aviação Expedicionária a Moçambique (Expeditionary Aviation Squadron at Mozambique)". In 1919 he was laureate "for the strong commitment that he has shown in the prompt repair of seaplanes that were cooperating in operations at Aveiro against monarchist rebels, proving his professional resources and demonstrating the utmost dedication and value in carrying out missions which he was in charge". In 1920 he was laureate "for having made the Calshot-Lisbon air trip by the Portuguese seaplanes, which was an honorable and dignity trip, not only for its execution, as well as for the laborious and careful preparation, that was considered as extraordinary and important rendered services". In 1921 he was laureate "for carrying out the Lisbon-Madeira air trip". On March $30^{\text {th }} 1922$, he was promoted Commander with distinction. Later in the same year he was laureate "for carrying out the first flight from Europe to the South Atlantic, Lisbon-Rio de Janeiro". In 1925 he was posthumously laureate "for the services to Aviation as Director da Aeronáutica Naval (Naval Aeronautics Director), by whom he did every possible sacrifice and still by the important and extraordinary commission performed at Fokker 4146, in which he suffered the disaster that led to its disappearance". Other kinds of honors were given to Sacadura: villages christened with his name. Several cities of Portugal and former colonies, paid tribute to the Commander, by christening streets, avenues, squares, airports, with his name. The Portuguese Government pays tribute to Commander Sacadura Cabral by making issue of paper notes with his portrait; Portuguese Navy pays tribute to Commander Sacadura Cabral by christening a frigate with his name (Figure 16).

\section{Conclusion}

Sacadura Cabral was born in May $23^{\text {rd }} 1881$ at Celorico da Beira near the Portuguese higher mountains (Serra da Estrela) at the center of Portugal. In the few years that he had been shipped, always at the Mozambique coast, Sacadura became familiar with the sea services and knew all the ports of that Ultramarine Province. In carrying out geodetic and geographical missions, Sacadura Cabral and Gago Coutinho worked together from 1907 to 1910. Sacadura Cabral revealed in this work his skills as a geographer, astronomer and organizer. In 1915, with 34 years old, Sacadura started to serve the Country the Aviation. After a brief period as a pilot instructor, he became responsible to defend Portuguese interests at Mozambique against Germany. He proposed himself to organize the attempt to Lisbon-Rio de Janeiro Atlantic cross. He invited Coutinho to devote himself to the air navigation problem and on his own decision deepened in the study of a device that could compensate the drift caused by wind. He tested these instruments in 1920. In 1921 with the help of precision instruments he reached a perfect straight line between Lisbon and Funchal. In 1922 Sacadura with Coutinho as navigator and observer performed for the first time in History, the First Cross of Atlantic South only with the help of instruments onboard. In 1923 he started to organize the attempt of the First Aerial Circumnavigation Journey, together with
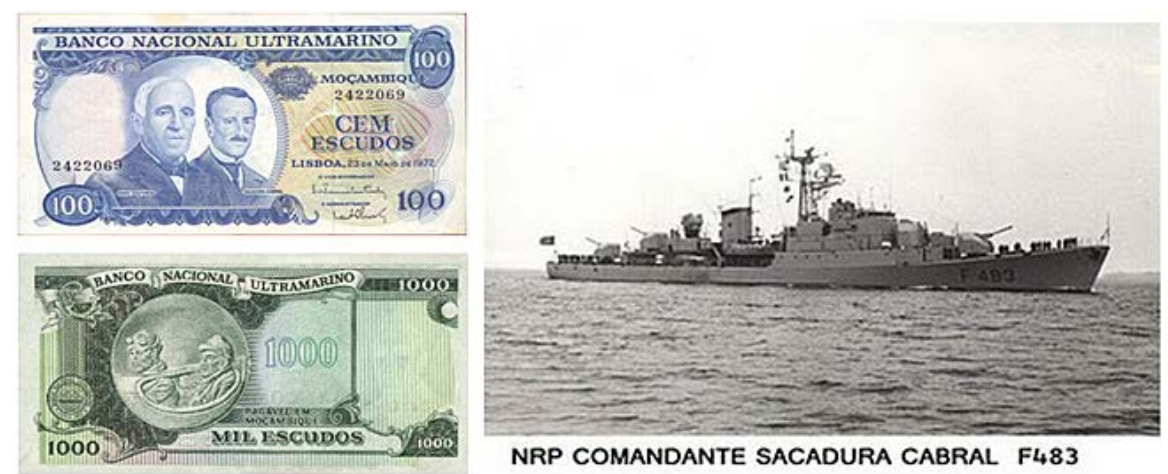

Figure 16. On the left side: Some paper money tribute to Sacadura Cabral: two of the three bank notes issued at Mozambique, circulating from 1972 to 1975; on the right side: Portuguese Navy pays tribute to Commander Sacadura Cabral, by christening the Navio da Républica Portuguesa Frigate, with his name. 
Brazil. Sacadura had invoked the Portuguese people that this journey around the World the Portuguese should be pioneers for historical reasons. The internal bureaucratic processes lived in the Country had delayed Sacadura's project far beyond [2]. Sacadura had foreseen the use of the aircrafts for air transport at the future. On November $15^{\text {th }}$ 1924, he died somewhere at the English Channel, while piloting a Fokker 4146 from Amsterdam to Lisbon, one of five planes that had been acquired by public subscription and that would be used in the air travel to India as a beginning of a circumnavigation. The corpse was never found. The sea kept for always the body of a Great Portuguese Citizen.

\section{Acknowledgements}

The present work was performed in the scope of the activities of the AeroG-Aeronautics and Astronautics Research Center (http://aeronautics.ubi.pt). The financial support of the Portuguese Ministry of Science through the Science and Technology Foundation (FCT) is gratefully acknowledged.

\section{References}

[1] Cardoso, E.P.C. (1981) História da Força Aérea Portuguesa, Vol. I, Edição Cromocolor, Lda, Lisboa, Printed in Gratelo, S.A.R.L., 2700 Amadora.

[2] Corrêa, P. (1964) Sacadura Cabral, Homem e Aviador. Edição do Autor, Lisboa.

[3] Neves, F.M.S.P., Barata, J.M.M. and Silva, A.R.R. (2010) Gago Coutinho and the Aircraft Navigation. Proceedings of the 48th AIAA Aerospace Sciences Meeting Including the Horizons Forum and Aerospace Exposition 2010, 3, 18231832. http://dx.doi.org/10.2514/6.2010-156

[4] Santos, J.T. (1978) Aviação Naval, Revista da Armada, Nos. 81 e 82 de Junho e Julho de 1978.

[5] Silva, A.R.R., Morgado, C.M.P., Barata, J.M.M. and Neves, F.M.S.P. (2009) First Flight from Europe to the South Atlantic-Gago Coutinho and Sacadura Cabral. Proceedings of the 47th AIAA Aerospace Sciences Meeting and the NewHorizons Forum and Aerospace Exhibit 2009, 21, 13670-13676.

[6] Albuquerque, L. (1989) Curso de História da Náutica. Alfa, Lisboa.

[7] Boléo, J.O. (1972) Gago Coutinho e Sacadura Cabral. Sociedade de Geografia, Lisboa.

[8] Corrêa, P. (1969) Gago Coutinho, Precursor da Navegação Aérea. Portucalense Editora, Porto.

[9] Lemos, S. and Oliveira, C.M. (2000) O Almirante Gago Coutinho. Instituto Hidrográfico, Lisboa.

[10] Reis, M. and Cortesão, A. (1969) Gago Coutinho Geógrafo, Coimbra, Junta de Investigações do Ultramar, 1970, sep. de Memórias da Academia das Ciências de Lisboa, Tomo XIII.

[11] Barata, J.M.M., Mendes, A.L.M., Morgado, C.M.P., Neves, F.M.S.P. and Silva, A.R.R. (2009) The Origins of Scientific Aircraft Navigation. Proceedings of the 45th AIAA/ASME/SAE/ASEE Joint Propulsion Conference \& Exhibit and 7th International Energy Conversion Engineering Conference 2009, 3, 1974-1980.

[12] Cardoso, E.P.C. (1981) História da Força Aérea Portuguesa, Vol. II, Edição Cromocolor, Lda, Lisboa, Printed in Gratelo, S.A.R.L., 2700 Amadora.

[13] Cruz, J.A. (2000) Sacadura Cabral, o Homem que Deu Asas à Marinha, Revista da Armada, nº 330 e 331 , Abril e Maio de 2000.

[14] Ciência em Portugal, Personagens e Episódios, Sacadura Cabral (1881-1924). http://cvc.instituto-camoes.pt/ciencia/p28.html

[15] Flight-Official Organ of the Royal Aero Club of the United Kingdom (1924) The Fokker T-III Monoplane. No. 807, No. 24, Vol. XVI, June 12, 1924, p. 389. 